Nif,A Technical Memorandum 83557

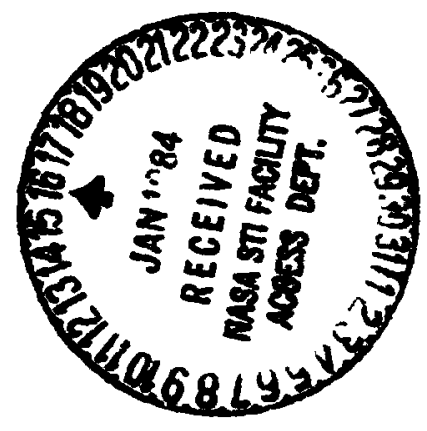

\title{
Heat Transfer Distributions Around Nominal Ice $t$-ccreition Shapes Formed on a Cylinder in thu NASA Lewis Icing Research Tunnel
}

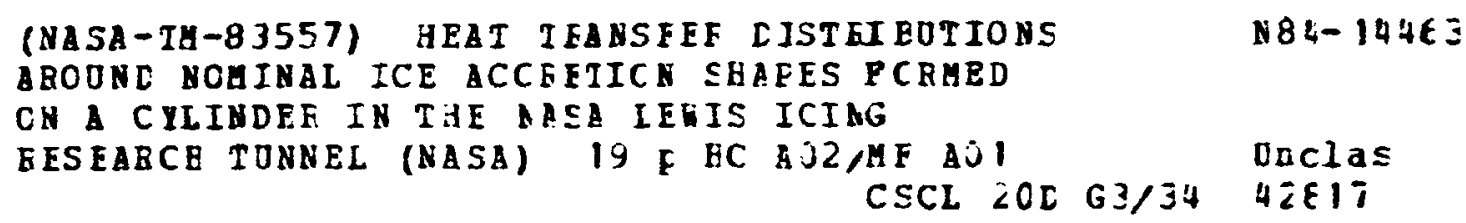

G. J. Van Fossen, R. J. Simoneau, W. A. Olsen, Jr., and K. J. Shaw

Lewis Research Center

Cleveland, Ohio

Prepared for the

Twenty-second Aerospace Sciences Meeting sponsored by the American Institute of Aeronautics and Astronautics Reno, Nevada, January 9-12, 1984 


\section{ORICWNAL PAGE IS
OF POOR QUALTY}

HEAT TRANSFER OISTRIBUTIONS AROUND MOMIMAL ICE ACCRETION SHAPES FORMED

ON A CYLIMDER IN THE MASA LEWIS ICIMG RESEARCH TUWWEL

6. J. Van Fossen, R. J. Simoneau, W. A. Olsen, and R. J. Shaw

Mational Aeronautics and Space Adninistration

Lewis Research Center
Cleveland, Ohio 44135

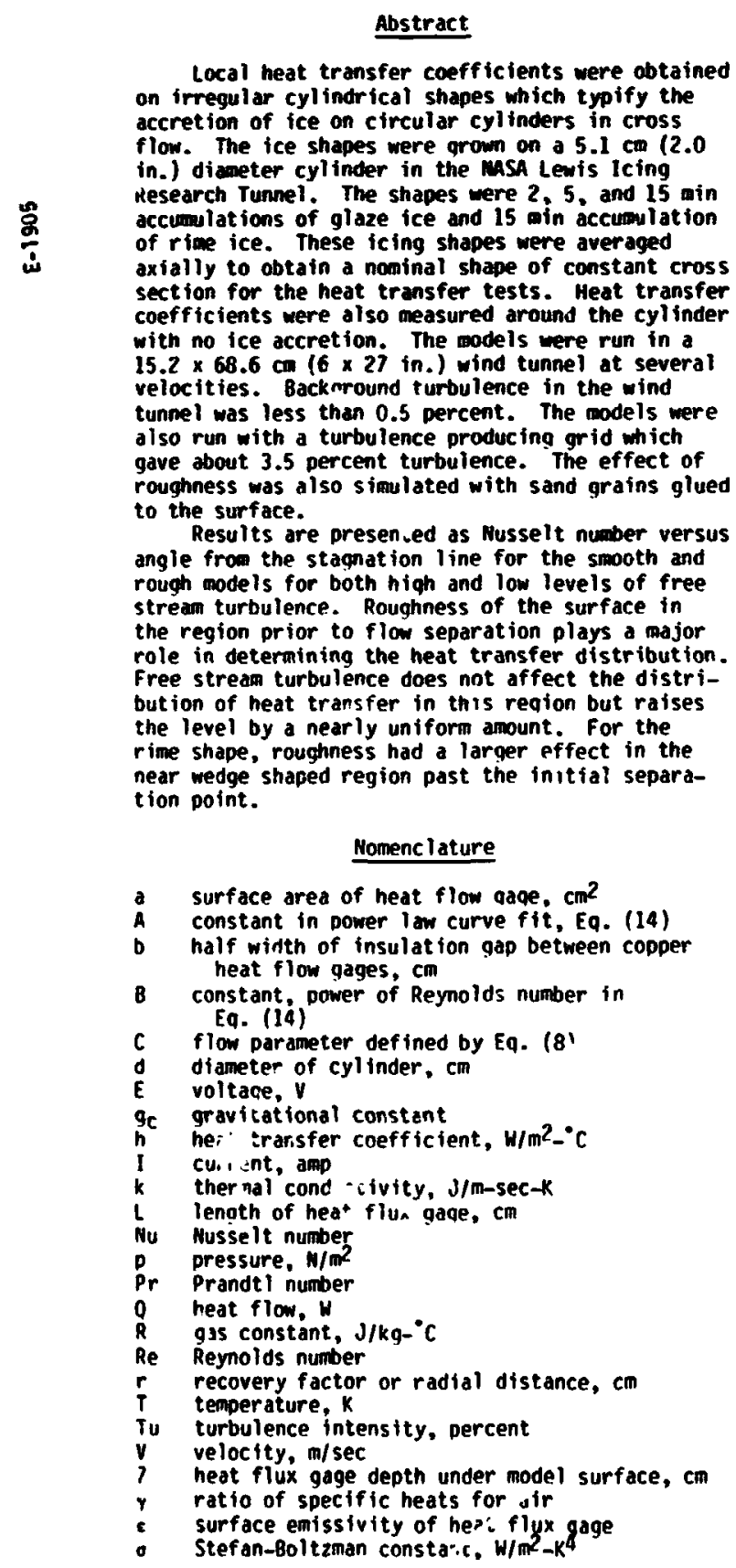

u viscosity, $\omega-\sec / \mathrm{m}^{2}$

D density, $\mathrm{kg} / \mathrm{m}^{3}$

Subseripts

a arbient surroundings

ad adiabatic wall temperature

gap in the space between copper heat flux gages

i iteration index

at reference conditions

rad radiation

s static conditions

s total conditions

t watl (copper strip)

\section{Introduction}

A portion of the MASA Icing Research Program involves development of computer codes that predict the accretion of ice on surfaces. Experiments show that the ice shape changes drastically in show that the ice shape changes drastically if
shape and roughness for different conditions. 1,2 Existing codes show that the predicted ice shapes are very sensitive to the assumed heat transfer coefficient distribution. 3 Unfortunately no data for heat transfer coefficients over smooth or rough ice shapes exists in the literature.

In an effort to correct this deficiency, heat ansfer coefficient distributions were measured on simulated ice accretion shapes. A range of ice shapes were obtained on a circular cylinder in the MASA Lewis Icing Research Tunnel (IRT). These shapes were axially averaged to obtain a representative ice shape with constant cross-section. Heat transfer models of these axially averaged shapes were then cast. from polyurethane foam. Electrically heated copper strips embedded in the model surface were used to measure the heat transfer coefficient distributions around the circumference of each model. Heat transfer distribitions were measured in dry air over a ranqe of velcicities with these models. Sand was later added to the surface of the models to determine the effect of roughness. The effect of free stream turbulence roughness. The effect

was also investigated.

Resuits are presented as Nusselt number versus anole from the stagnation line for the smooth and rough models for both high and low levels of free strean turbulence. The effect of Reynolds number on Nusselt number is also presented for selected locations on each model. A table of curve fits of Nusselt number as a funct ion of Reynolds number for each heat transfer gage is also presented.

\section{Test Specimens}

Heat transfer coefficient distributions were measured around models of four ice accretion shapes. The fce shapes were grown on a $5.1 \mathrm{~cm}$ (2.0 in.) dianeter circular cylinder in the MASA (2.0 in.) diameter circular cylinder in the MASA
Lewis I I ing Research Tunnel (IRT). The shapes were 2-, 5-, and 15-min accumulations of glaze ice and 15-min accumulation of rime ice. These icing shapes were averaged axially to obtain a nominal 


\section{ORIGINAL PAge is OF POOR QUALITY}

shape of constant cross section for the heat transfer tests. This was accomplished by allowing the ice to accrue for the required time on the 5.1 $c(2.0$ in) cylinder. Figure 1 shows both glaze and rime ice that accrued on a cylinder in the IRT under similar conditions. The ice was then cut perpendicular to the axis of the cylinder at the tunnel centerline and at locations $\$ 5.1 \mathrm{~cm}(2.0$ in.) from the centerline. Tracinas of these crosssections were then superimposed and an average curve was drawn through them. The four icing shape heat transfer models are shown in $\mathrm{Fig} .2$. The dimensionless coordinates, as defined on $\mathrm{Fiq}, 3$ for each ice shape are given in Table 1 .

Each model was $15.2 \mathrm{~cm}(6.0 \mathrm{in}$.) long. A 5.1 car (2.0 in.) circular semi-cylinder was attached to the rear of each model shown in $\mathrm{Fig} 2$ durina testing to assure geometric similarity with the ice shapes arown in the IRT.

The icing shape heat transfer models were cast of a polyurethane foam. Axially averaged cast of a polyurethane foam. Axialiy averaged circumference of each model by using electricall circumference of each model by using electrically in.) Jona by $0.51 \mathrm{~cm}(0.20 \mathrm{in.})$ wide and $0.318 \mathrm{~cm}$ ( 0.125 in.) deep. A typical copper strip heat flux gage is shown in Fio. 4. A Kapton encapsulated electric heater was fastened to each copper strip with a pressure sensitive adhesive. A stainless steel sheathed, closed, grounded ball. Chromel-Alumel thermocouple was soft soldered into a groove in each copper strip.

The copper strips were embedded in the polyurethane foan at clusely spaced intervals along the circumference of each model. The location of the qages for each icing model is shown in Table II. The surface of each model had a thin coating of clear lacquer to keep the copper gages from oxidizing and chanaing emissivity. As will be shown later, the increased thermai resistance of the lacouer coating did not adversely affect the results.

A large copper plate with a heater and thermocouple similar to the surface aages was embedded in the center of each model to act as quard heater. The temperature of the quard plate was adjusted to be the same as that of the heat flux qages thus minimizing heat loss thru the rear of the model.

Heat transfer coefficients were also measured around the cylinder with no ice accretion. The circular cylinder model was made of wood instead of the polyurethane foam. The cylinder heat transfer model is shown in Fig. 5. The circular cylinder model was $6.6 \mathrm{~cm}(2.6 \mathrm{in.})$ in diameter and $15.2 \mathrm{~cm}$ (6.0 in.) long. The same copper strip heat flux gages were used in the cylinder as in the icing shape models. A rear guard heater was also used on this model. In addition to the rear guard heater, guard heaters were added at the ends of the heat flux gages because the wood used had a higher thermal conductivity than the polyurethane foam.

In order to more closely simulate the small scale surface roughness of ice, artificial roughness was added to the models for some of the tests. This was accomplished iy sproying a coat of clear lacquer onto the model, sand was then sprinkled on the wet surface from an ordinary salt shaker.

Another thin coat of lacauer then held the sand in place. A profflometer was used to try and measure the roughness but the roughness elements were too large for this instrument. An optical comparitor was used to obtain an est imate of the roughness. The maximum height of any one roughness element was found to be $0.0572 \mathrm{~cm}(0.0225 \mathrm{in.})$. The average helght of the roughness elements above the surface was $0.033 \mathrm{~cm}(0.013 \mathrm{in}$.)

\section{Apparatus}

The icing shape heat transfer tests were conducted in the wind tunnel shown schematically in Fig. 6. Roo air first flaved through a turbulence damping screen with an $18 \times 18$ mesh of $0.24 \mathrm{~mm}$ $(0.0095$ in.) diameter wire. Large scale turbulence from the room was then broken up by flowing thru approximately 12000 plast ic soda straws which were $0.64 \mathrm{~cm}(0.25 \mathrm{in.})$ in dianeter by $19.69 \mathrm{~cm}$ (7.75 in.) long. The air then passed through (7.75 in.) long. The air then passed through

A $4.85: 1$ contraction then accelerated the air entering the test section. The maximum velocity attainable in the test section was about $46 \mathrm{~m} / \mathrm{sec}$ (150 ft/sec, $102 \mathrm{mph}$ ) and the clear tunnel turbulence level was less than 0.5 percent at all flow rates. For the high turbulence cases, turbulence generating biplane grid of $0.318 \mathrm{~cm}(0.125 \mathrm{in.})$ rods spaced 6 rod dianeters apart was installed 90 rod diameters $(28.58 \mathrm{~cm}(11.25$ in.)) upstrean of the model leading edge.

The test section was $15.2 \mathrm{~cm}(6.0 \mathrm{in.})$ wide by $68.6 \mathrm{~cm}(27.0 \mathrm{in.}) \mathrm{high}$. The models were mounted horizontally in the tunnel. Hot wire sur-
veys indicated that the center $7.6 \mathrm{~cm}(3.0 \mathrm{in}$.) of veys indicated that the center $7.6 \mathrm{~cm}(3.0 \mathrm{in}$.) the sidewalls. The heat flux gages were $6.6 \mathrm{~cm}$ (2.6 in.) long and thus did not extend into the region of turbulence generated by the sidewalls.

After leaving the test section, the flow passed through a transition section into a 10 in. pipe, through two long radius elbows, a flow straightener and into an orifice run. The orifice plate had a diameter of $19.1 \mathrm{~cm}(7.5 \mathrm{in.})$. The flow rates used in these tests were measured with this orifice. Air then passed thry a 10 in. butterfly valve which was used to control the flow rate and then to the building altitude exhaust system.

The temperature of the air entering the wind tunnel was measured by four exposed ball chromelAlumel thermocouples around the perimeter of the inlet. The output of these four thermocouples were averaged to give the total or stagnation temperature.

Turbulence measurements were made with a DISA model $55 \mathrm{MO}$ constant temperature hot wire anemometer. Signals were linearized with a DISA model 55M25 inearize.. The mean component of the turbulent velocity signal was read on a OISA model 55031 integrating digital voltmeter. The fluctuating component was read on a DISA model 55035 RMS voltmeter. Both these instruments have an adjustable time constant which was adjusted to the minimum value which would give a stable reading. minimum value which would give a stable readina.
The hot wire probe was a Thermosystems inc. model 1227-T1.5. This is a $4 \times 10^{-6}$ meter tunqsten sinale wire probe. The hot wire was calibrated before each use in a free jet of air at nearly the same temperature $\left( \pm 1^{\circ} C\right)$ as the wind tunnel flow. The hotwire system frequency response was determined to be around $30 \mathrm{kHz}$ by the standard square wave test. All hot wire measurements were made without the models in place and at the location of the cylinder center line.

Turbulence scale was estimated using an autocorrelation of the hot wire signal. The autocorrelation was obtained on a Wicolet model 660 A dual channel spectrum analyzer. The area 


\section{ORIGINAL PAGE is OF PCOR QUJALITY}

under the autocorrelation function gave an integral time scale. This time scale was then multiplied by the mean velocity to obtain a measure of the integral length scale.

During each heat transfer test, power to each heat flux gage was adjusted to keep the surface of the model at constant temperature. This was done manually at first and required about one hour to attain equlibrium for each daca point. An electronic circuit was designed to accomplish this task and the time to set each data point fell to task and the time to set each data point fell to
about 5 min. A block diagram of the circuit is shown in Fig. 7. The voitage from the thermocouple was amplified and compared to an adjustable reference voltage which was the same for all heaters on the model. The offference in these two voltages was anplified and applied to the base of a power transistor which then controlled the power to each heater. Current was measured with the $0.05 \mathrm{ohm}$ shunt and voltage was measured across each heater thus allowing the calculation of electric power dissipated.

\section{Data Reduction}

\section{Heat Transfer Coefficient}

The heat transfer coefficient for each copper strip was calculated from the valtace, and current applied to the heater and the temperature measured by the thermocouple. It was desired to know the heat transfer due only to convection; therefore, the heat lost by radiation had to be subtracted from the electric power input. This contribution was est imated as

$$
Q_{\text {rad }}=\operatorname{ode}\left(T_{w}^{4}-r_{a}^{4}\right)
$$

The surface emissivity, $c$, was estimated as 0.5 . The radiation contribution for most cases was less than 2 percent of the total heat flow.

The copper strips were separated by a small gap which contained the polyurethane foam. Some heat is conducted from the edge of the copper strip, through the foam and convected from the surface of the model. An est imate of this heat loss was obtained from an exact solut ion ${ }^{4}$ for the heat conduction in a rectangle with two ad jacent sides insulated, one other side held at constant temperature (the temperature of the copper strip) and the final side convecting to a fluid at a known temperature. The solution is

$$
0_{g a p}=2 h\left(T_{w}-T_{a d}\right) L \sum_{n=1}^{\infty} \frac{\tan a_{n} 2 \tanh a_{n} b}{\left[a_{n}^{2}+\left(\frac{h}{k}\right)^{2}\right] 2+\frac{h}{k}}
$$

where the $a_{n}$ 's are the rnots of

$$
a_{n} \tan \left(a_{n} z\right)=\frac{h}{k}
$$

A drawing of this area is shown in Fig. 8. A detailed finite difference model of the area between the dashed lines in the fiqure showed that virtually no heat was lost from the bottom side of the copper strip. The finite difference solution and the exact solution gave the same value for the heat lost in the gap to within 2 percent. The exact solution was used in the data reduction to account for the heat loss thru the qap. The heat lost thru the gap varied from 10 percent to as much as 20 percent for large qaps.
The heat transfer coefficient was then calculated as

$$
h=\frac{E I-Q_{\text {rad }}-Q_{\text {gap }}}{a\left(T_{w}-T_{\text {ad }}\right)^{2}}
$$

Note that to calculate $Q_{\text {gap, }}$ the heat transfer coefficient, $h$, must be known. Thus an iterative solution was necessary. An initial guess was made for $h$ from Eq. (4) by assuming $Q_{g a p}$ was zero, $Q_{\text {gap was then calculated and Eq. (4) used to }}$ recalculate $h$. This procedure was repeated unti

$$
\left|n_{i+1}-n_{i}\right|<0.001
$$

Test Section Density-Velocity Product

With no models present, the velocity in the test section was measured with a pitot-static probe. The density was calculated assuming air to be an ideal gas. The Jensity-velocity product in the test section was tivein correlated to the or iffice flow rate. This correlation was then used to calculate the density-velocity product in all subsequent tests.

\section{Test Section Static Pressure}

Test section static pressure was not measured so an estimate was made using Bernoulli's equation for incompressible flow. Test section static pressure was calculated as

$$
P_{s}=P_{t}-\frac{1}{2} \rho v^{2}
$$

The total pressure, $p_{t}$, was assumed to be the local barometric pressure. The density-velocity product was known from the correlation mentioned in the previous section. To calculate the density, the static pressure must be known; thus, iteration was required to obtain a solution to Eq. (6).

\section{Test Section Static Temperature}

Total temperature was measured at the inlet to the turbulence control section. Test section static temperature was calculated for a perfect gas under adiabatic conditions as

$$
T_{s}=\frac{-1+\sqrt{1+\frac{4 C T_{t}}{p_{s}^{2}}}}{\frac{2 C}{p_{s}^{2}}}
$$

where

$$
C=\frac{y-1}{2}(o v)^{2} \frac{R}{r g c}
$$

The ratio of specific heats for air, $r$, was assumed to be 1.4 and the gas constant, $R$, was 286.91 $J / k g-C(53.35 \mathrm{ft}-1 \mathrm{bf} / 1 \mathrm{bm}-\mathrm{R})$.

\section{Adiabatic Hall Temperature}

as

The adiabatir nall temperature was calculated

$$
T_{\text {ad }}=T_{s}+r\left(T_{t}-T_{s}\right)
$$




\section{ORIGINAL PACE IS \\ OF POOR QUALITY}

The recovery factor, $r$, was assumed to be

$$
r=\sqrt{\mathrm{Pr}}
$$

\section{Thermal Properties}

Thermal conductivity, viscosity, and Prandt l number for air were obtained as a function of temperature from curve fits of data presented in Ref. 5. Thermal properties were evaluated at the Eckert reference temperature given by 6

$$
T_{r}=0.5 T_{w} \cdot 0.28 T_{s}+0.22 T_{a d}
$$

\section{Reynolds Number}

The Reynolds number for all models was based on the diameter, $d$, of the bare cylinder. For the ice shapes this was $5.1 \mathrm{~cm}(2.0 \mathrm{in.})$ and $6.6 \mathrm{~cm}$ $(2.6 \mathrm{in.})$ for the cylinder with no ice accumulation. The Reynolds number was calculated as

$$
R e=\frac{\rho V d}{\mu}
$$

\section{Nusselt Number}

The Nusselt number was also based on the diameter of the bare cylinder with no ice accum lation and was calculated as

$$
\text { Mu }=\frac{h d}{k}
$$

\section{Data Acquisition and Error Analysis}

All data with the exception of the turbulence measurements were recorded on the laboratory data acquisition system which is described in Ref. 7 . For each data point, twenty "scans" or individual readings of each data channel were recorded. These readings of each data channel were recorded. These reading for each channel. This helped to eliminate some of the noise present in the system. Because of the electronic multiplexing of the individual data channels to the analog to digital converter, there is a certain offset between data channels. In an extreme case this caused a 0.6 chandicated difference in themocouples that were at the same difference in thermocouples that were at the same the inputs to the data acquisition system after a run, recording this value, then subtracting this "zero" from each reading.

An error analys is was performed for each data point by the method of $K 1$ ine and MCC lintock. 8

The average error for all data points was determined to be 5.7 percent and the maximum error was 7.8 percent.

\section{Results and Discussion}

In this section, heat transfer distribution in the form of Nusseit number as a function of angle from the stagnation point as well as the variation of Nusseit number with Reynolds number will be presented for the circular cylinder and the four fce accretion shapes. Results will be presented for both smooth and sand roughened shapes for high and low free stream turbulence.
Heat Transfer Distributions

\section{Circular Cylinder}

Smoot', Surface-Low Turbulence. Figure 9 shows Nusselt nun $3 r$ as a function of angle from the stagnation point for the four cases mentioned above. All the data on Fig. 9 was taken at a Reynolds number of 177000 .

A iso ploted on the figure is an exact solution of the lamina: boundary layer equations due to frössling. 9 The good agreement between the exact solution and the smooth cylinder. low turbulence data confirms the accuracy of the experimental method.

Smooth Surface-High Turbulence. Nusselt number distribution around the cylinder placed downstrean of the bi-plane grid is also shown on fig. 9 . The grid produced turbulence of about 3.5 percent with a scale of $1 \mathrm{~cm}(0.4 \mathrm{in.})$. Three and one-half percent turbulence was selected because the IRT was originally thought to be a "dirty" tunnel with about this level of turbulence. Recent hot wire measurements by the authors have shown that in fact the turbulence levels are much closer to 0.5 percent. The effect of turbulence is to increase the heat transfer virtually uniformly around the circumference (measurements were only made up to $50^{\circ}$ from staqnation) by about 30 percent.

Rough Surface-Low Turbulence. As seen on Fig. 9 , the addition of sand roughness to the cylinder surface does not change the heat transfer rate near the stagnation point from the smooth surface case. As the anqle from stagnation increases however, the heat transfer rate also increases. This is most likely due to boundary layer transition.

Rough Surface - High Turbulence. The final set of symbols on fig. 9 is for the sand roughened surface with 3.5 percent free stream turbulence. The effect of free stream turbulence is seen to be greater nearest the stagnation point where the heat transfer rate is aqain increased by about 30 percent over the low turbulence case. As the angle from stagnation becomes laraer, the effect of free stream turbulence diminishes as the boundary layer becones more turbulent.

\section{Two Minute Glaze Ice}

Figure 10 shows the Nusselt number distribution for a two minute accumulation of glaze ice. The data on this figure was taken at a Reymolds number of 136000 . Also shown on the fiqure is the exact solution due to Frösslina.

Smooth Surface-Low Turbulence. For the smooth surface, low turbolence case, the heat transfer distribution is not changed much from the circular cylinder. There is no gage at the stagnation point but qage number 5 shows that the heat transfer in the staqnation region is only slightly below that for the cylinder. Gages 2, 3, and 4 show only slightly higher heat transfer than the circular cylinder. Gage number 1 is in a region of separated flow and has a somewhat higher heat transfer rate. This region is of relatively low importance because the water drop collection efficiency in this region is near zero and ice does not qrow this region is near
from this location. 


\section{ORIGUNA
OF POOR Ga is}

Rough Surface-Low Turbulence. As with the circular cylinder, the addition of surface roughness arastically changes the heat transfer distribution. The heat transfer in the stagnation region remains nearly the same as for the smooth surface but boundary layer transition causes the heat transfer to nearly triple at gage number 2 . The collection efficiency is high in this region and the large heat transfer promotes rapid ice arowth. Rough Surface-High Turbulence. The addition of free stream turbulence lncreases the heat transfer in the stagnation region. Heat transfer in the region of ice growth is not significantly affected by turbulence however. Turbulence has no effect on heat transfer in the separated region (gage 1).

\section{Five Minute Glaze Ice}

The heat transfer distribution for five minutes accumulation of glaze ice is shown on Fig. 11 . The exact solution is again shown for reference. Reynolds number for these data was 140000

Smooth Surface-Low Turbulence. For this case near the staqnation region (qage 8), the heat transfer is 23 percent lower than for the circular cylinder. As the angle from stagnation increases. the heat transfer increases slightly then decreases to a minimum at qage 6 . Heat transfer is a maximum at gage 4 .

Rough surface-Low Turbulence. In the stagnation region, heat transfer is the same as the smooth surface case. As with the cylinder, roughness causes the heat transfer to increase dramatically with distance from the stagnation point. The maximum heat transfer rate occurs at oage 4 and is nearly double that of the smooth surface case. It is obvfous from examination of the ice shape that the region near gage 4 is the region of fastest ice growth. Roughness does not affect the heat transfer rate in the separated regi in (gages 1,2 , and 3 ).

Rough Surface-High Turbulence. Turbulence has the same effect on heat transfer as in the previous examples. Heat transfer is increased in the stagnation region and the increase is not as great in the region of fastest ice arowth away from the stagnation region. Turbulence has virtually no effect in the separated region.

\section{Fifteen Minute Glaze Ice}

Figure 12 shows the heat transfer distribution for 15-min accumulation of alaze ice. The Reynolds number for all the data on this fiqure was 136000 . Frössling's exact solution for the cylinder is again platted for reference.

Smooth Surface-t ow Turbulence, Smooth surface results are similar to the previous qlaze ice shapes. Heat transfer is lower than for the cylinder near the stagnation region and increases to a maximum at gage 9 which is the location of fastest ice accumulation.

Smooth Surface-High Turbulence. The effect of higher turbulence with the smooth surface is again to increase heat transfer nearly uniformly except in the separated flow region where there is no effect.

Rough Surface-Low Turbulence. Roughness has almost no effect unt transfer rate is doubled compared to the smooth surface low turbulence case.

Rough Surface-High Turbulence. Turbulence as in alt the other cases, causes a nearly uniform increase in the heat transfer except in the separated flow region.

\section{Fifteen Minute Rime Ice}

Figure 13 shows the heat transfer distribution for 15-min accumulation of rime ice. All data points were taken at a Reynolds number of 138000 . Smooth Surface-Low Turbulence. Heat transfer levels for the rime ice shape are similar to those for the plane cylinder except near gage 8 where they are slightly higher. It was impractical to locate a gage at the critical region between gages 8 and 9; it is possible that the maximum heat transfer rate occurs at this location.

$$
\text { Smooth Surface-High Turbulence. A nearly }
$$
uniform increase can be seen in the stagnat ion region. In the wedge shaped region (gages 1 to 7 ) there is no effect of turbulence.

Rough Surface-Low Turbulence. The largest increase in heat transfer due to roughness occurs at gage 8. Roughness also increases the heat transfer in the wedge flow region considerably and has less of an effect in the stagnation region.

It is possible that roughness causes an even more oramatic increase in the critical region between gages 8 and 9 that cannot be resolved.

Rough Surface-High Turbulence. As in all the previous cases turbulence increases heat transfer in the stagnation region by the largest amount. Heat transfer is increased in other regions by turbulence but to a lesser degree.

\section{Reynolds Number Effects}

Data for all models was taken for various flow rates which gave a range of Reynolds numbers from about 50000 to 180000 . Space limitations prevent us from showing Reynolds number effects for every gage of every model; however, results for every gage of every model; however, results from gages in critical ice growth areas and ot
interesting locations will be shown. For each gage, a least squares $f$ it of the equation

$$
N u=A R e^{B}
$$

was obtained, the constants $A$ and $B$ for each gage are shown in Table III.

\section{Circular Cylinder}

Figure 14 shows Nusselt number as a function of Reymolds number for the gage located at $50^{\circ}$ from the stagnation point for the circular cylinder. This is near the location of most rapid ice accumulation. Also shown on the figure is a least squares fit of Eq. (14) for each case. The constants $A$ and $B$, are shown on the legend of the figure as well as in Table III.

for the smooth surface cases of 10 and high free stream turbulence, the slope of the curves is seen to be near 0.5 which is indicative of a laminar boundary layer. The addition of surface roughness causes a departure from the power law behavior which is indicative of a transitional boundary layer. In the latter two cases, the least squares fits were computed only for data points with Reynolds numbers greater than 100000 .

\section{Glaze Ice}

The effect of Reynoids number on Musselt number for 2-min accumulation of glaze ice for gage 


\section{ORIGNAL PACE IL.
OF POOR QUALTTY}

two is shown on Fig. 15. The behavior is similar to that shown previousiy for the cylinder. The smooth surface case has a 0.5 slope indicating a laminar boundary layer. The addition of surface roughness causes boundary layer transition and a departure from the power law curve fit.

The remaining two glaze ice shapes tested, 5and 15-min accumulation, show similar trends with Reynolds number and will not be shown here.

\section{Rime Ice}

The effect of Reynolds number on heat transfer at gage 9. which is near the location of fastest ice growth, is shown on Fig. 16. The two smocth surface cases have slopes near 0.5 which indicates a laminar boundary layer. The two cases with surface roughness shown an increased slope but, unlike the glaze ice, follow the power law curve $f i t$. Figure 17 shows the data from gage 4 . In

this region the ice shape appears wedge-like, i.e., a nearly flat surface at an angle to the free stream. The smooth surface data appears to 90 thru a rapid transition to a turbulent boundary layer as Reynolds number increases beyond about 70000 . In all cases where this transition takes place, the constants in Table III are valid only for the high Reynoids number portion of the data. The addition of surface roughness or free stream turbulence, however, eliminates this phenomenon.

\section{Summary of Results}

Heat transfer measurements have been made on a circular cylinder and on four simulated ice accretion shapes. The ice shapes had a constant cross section perpendicular to the flow and were obtained by averaging cross sections of ice grown on a cylinder in the MASA Lewis Icing Research on a cylinder in the MASA Lewis icing Research circumference of the ice shapes and circular cylcircumference of the ice shapes and circular cylinder were obtained over a range of flow velocistrean turbulence was investigated for each icing shape model. The heat transfer distribution around each model is presented as well as selected Reyeach model is presented as well as selected ReyNusselt number as a function of Reynolos number are presented in tabular form. Major conclusions were:
1. Surface roughness changes the character of the boundary layer from laminar to transitional. This causes heat transfer to increase in the reqion of fastest ice growth.

2. Free stream turbulence changes heat transfer most in the stagnation region. The stagnation region is not the region of most rapid ice growth. 3. As glaze ice shapes grow, the difference between heat transfer at the stagnation point and the point of the most rapid growth increases thus promoting even faster growth away from the stagnation region.

\section{References}

1. Shaw, K. J., Sotos, K. G., ano Solano, F R.,: "An Experimental Study of Airfoil Icing Characteristics," MASA TM-82790, 1982.

2. Ulsen, W. A. J., and Shaw, R. J., "Ice Shapes and the Resulting Aero Penalty for a Typical Helicopter Airfoil," AIAA Paper 84-0109, 1984.

3. Lozowski, E. P., Stall labrass, J. R.. ano Hearty, P. F., "The Icing of ar Inheated Mon-rotating Cylinder in Liquid water Droplet: Ice Crystal Clouds, "Naticnal Research Council of Canada, LTR-LT-96, FeD. Research
1979.

4. Carslaw, H.S., ana Jeager, J.C.. Conouction of Heat in Solids, 2no eo. , Clarenoon Press, Oxford, 1959, P. 167

5. Hillsenratn, J., Beckett, C. W., Benedict, W. S., Fano, L.., and Hobe, H. J.," "Tables of Thermal Properties of Gases." NBS Circular 564, Mov. 1955.

b. Eckert, E.R.G., ana brake, R.M., Heat ana Mass Transfer. 2nd eo., McGraw-HiTl, New York, 1959, D. 270.

7. Miller, R.L., "ESCORT: A vata Acquisition and Display System to Support Research Testing," MASA TM-78909, 1978.

8. Kline, $S$.J and McClintock, $F$. A. "Descrioing uncertainties in Single-Sample Experiments," Mechanical Engineering, Vol. 75, Jan. 1953, pp. 3-8.

9. Frössling, N., "Evaporation, Heat Transfer, and Velocity Distrioution in Two-Dimensional and Rotationally Symetrical Laminar Boundary-Layer Flow," NACA TM 1432, 1958. 
ORIGiNAL: PAEE IS

OF POOR QUALITY

TABLE 1. - ICE SHAPE COORIMATES*

\begin{tabular}{|c|c|c|c|c|c|c|c|}
\hline \multicolumn{2}{|c|}{ Two minute glaze } & \multicolumn{2}{|c|}{ Five minute glaze } & \multicolumn{2}{|c|}{ Fifteen minute glaze } & \multicolumn{2}{|c|}{ Fifteen minute $r$ ine } \\
\hline - & $2 r / d$ & $\bullet$ & $2 r / d$ & $\theta$ & $2 r / d$ & $\bullet$ & $2 r / d$ \\
\hline $\begin{array}{r}0.43 \\
7.85 \\
16.13 \\
23.03 \\
30.55 \\
37.91 \\
46.62 \\
51.52 \\
55.96 \\
59.50 \\
61.35 \\
63.51 \\
66.11 \\
69.65 \\
72.17 \\
74.66 \\
90.00\end{array}$ & $\begin{array}{l}1.173 \\
1.187 \\
1.204 \\
1.215 \\
1.231 \\
1.244 \\
1.269 \\
1.264 \\
1.237 \\
1.184 \\
1.148 \\
1.100 \\
1.062 \\
1.032 \\
1.035 \\
1.041 \\
1.000\end{array}$ & $\begin{array}{l}0.00 \\
5.04 \\
9.42 \\
11.74 \\
14.92 \\
18.27 \\
22.55 \\
25.97 \\
29.77 \\
33.71 \\
36.08 \\
38.60 \\
41.69 \\
43.91 \\
46.03 \\
47.90 \\
50.14 \\
52.43 \\
55.76 \\
60.93 \\
65.97 \\
71.21 \\
75.12 \\
89.43\end{array}$ & $\begin{array}{l}1.314 \\
1.379 \\
1.445 \\
1.461 \\
1.463 \\
1.451 \\
1.439 \\
1.438 \\
1.468 \\
1.532 \\
1.582 \\
1.639 \\
1.704 \\
1.717 \\
1.705 \\
1.660 \\
1.566 \\
1.454 \\
1.332 \\
1.198 \\
1.113 \\
1.064 \\
1.025 \\
1.001\end{array}$ & $\begin{array}{r}0.25 \\
1.72 \\
3.15 \\
4.60 \\
7.31 \\
10.20 \\
12.39 \\
15.03 \\
18.56 \\
21.66 \\
24.03 \\
25.86 \\
27.39 \\
28.94 \\
30.13 \\
31.24 \\
32.52 \\
34.31 \\
35.76 \\
37.09 \\
37.93 \\
38.87 \\
43.25 \\
53.32 \\
67.42 \\
75.49 \\
90.00\end{array}$ & $\begin{array}{l}1.921 \\
1.940 \\
1.971 \\
1.964 \\
1.932 \\
1.885 \\
1.877 \\
1.897 \\
1.951 \\
2.051 \\
2.214 \\
2.343 \\
2.484 \\
2.652 \\
2.818 \\
2.941 \\
3.003 \\
3.039 \\
3.031 \\
2.9904 \\
2.893 \\
2.766 \\
2.229 \\
1.566 \\
1.157 \\
1.028 \\
1.000\end{array}$ & $\begin{array}{r}0.00 \\
1.90 \\
4.49 \\
6.26 \\
8.07 \\
10.71 \\
14.46 \\
22.60 \\
35.23 \\
44.65 \\
53.01 \\
62.82 \\
69.96 \\
75.74 \\
89.42\end{array}$ & $\begin{array}{l}2.224 \\
2.257 \\
2.305 \\
2.305 \\
2.267 \\
2.131 \\
19.03 \\
1.532 \\
1.219 \\
1.104 \\
1.042 \\
1.022 \\
1.022 \\
1.034 \\
1.000\end{array}$ \\
\hline
\end{tabular}

*Parameters defined in Fig. 3.

TABLE II. - HEAT FLUX GAGE LOCATIONS*

\begin{tabular}{|c|c|c|c|c|c|c|c|}
\hline \multicolumn{2}{|c|}{ Two minute glaze } & \multicolumn{2}{|c|}{ Five minute glaze } & \multicolumn{2}{|c|}{ Fifteen minute glaze } & \multicolumn{2}{|c|}{ Fifteen minute rime } \\
\hline Gage no. & $\theta$ & Gage no. & $\theta$ & Gage no. & $\theta$ & Gage no. & $\theta$ \\
\hline $\begin{array}{l}1 \\
2 \\
3 \\
4 \\
5 \\
6\end{array}$ & $\begin{array}{r}62.4 \\
45.0 \\
33.0 \\
19.6 \\
7.0 \\
-5.4\end{array}$ & $\begin{array}{l}1 \\
2 \\
3 \\
4 \\
5 \\
6 \\
7 \\
8 \\
9\end{array}$ & $\begin{array}{r}67.0 \\
57.8 \\
52.5 \\
46.3 \\
36.0 \\
28.0 \\
19.0 \\
5.3 \\
-5.3\end{array}$ & $\begin{array}{r}1 \\
2 \\
3 \\
4 \\
5 \\
6 \\
7 \\
8 \\
9 \\
10 \\
11 \\
12 \\
13 \\
14 \\
15 \\
16 \\
17\end{array}$ & $\begin{array}{r}64.0 \\
57.1 \\
52.4 \\
48.2 \\
45.0 \\
42.8 \\
40.6 \\
38.6 \\
33.3 \\
29.1 \\
27.1 \\
24.4 \\
20.6 \\
15.6 \\
9.5 \\
2.8 \\
-2.8\end{array}$ & $\begin{array}{r}1 \\
2 \\
3 \\
4 \\
5 \\
6 \\
7 \\
8 \\
9 \\
10\end{array}$ & $\begin{array}{r}65.0 \\
51.6 \\
40.0 \\
31.3 \\
24.8 \\
19.4 \\
15.1 \\
11.0 \\
2.8 \\
-2.5\end{array}$ \\
\hline
\end{tabular}

tparameters defined in Fig. 3 . 


\section{oricinal page is OF POOR QUALITY}

TABLE III. - COEFFICIENTS FOR PONER LAN CURVE FIT OF NU - AReB FOR EACH CASE

\begin{tabular}{|c|c|c|c|c|c|c|c|c|c|}
\hline & \multirow[t]{2}{*}{$\begin{array}{l}\text { Gage } \\
\text { no. }\end{array}$} & \multicolumn{2}{|c|}{$\begin{array}{l}\text { Smooth surface } \\
0.58 \text { turbulence }\end{array}$} & \multicolumn{2}{|c|}{$\begin{array}{l}\text { Rough surface } \\
0.5 \% \text { turbulence }\end{array}$} & \multicolumn{2}{|c|}{$\begin{array}{l}\text { Smooth surface } \\
\text { 3.5\% turbulence }\end{array}$} & \multicolumn{2}{|c|}{$\begin{array}{c}\text { Rough surface } \\
3.5 \% \text { turbulence }\end{array}$} \\
\hline & & A & B & $A$ & B & A & B & A & B \\
\hline $\begin{array}{l}\text { Circular } \\
\text { cylinder }\end{array}$ & $\begin{array}{c}0^{\circ} \\
10^{\circ} \\
20^{\circ} \\
30^{\circ} \\
40^{\circ} \\
50^{\circ}\end{array}$ & $\begin{array}{l}1.2436 \\
0.9734 \\
0.8373 \\
0.8160 \\
0.6569 \\
0.6460\end{array}$ & $\begin{array}{l}0.4774 \\
0.5008 \\
0.5125 \\
0.5109 \\
0.55241 \\
0.5218\end{array}$ & $\begin{array}{l}0.7636 \\
0.3405 \\
0.0415 \\
0.0094 \\
0.0009 \\
0.0174\end{array}$ & $\begin{array}{l}0.5183 \\
0.6010 \\
0.7941 \\
0.9359 \\
1.1520 \\
0.9137\end{array}$ & $\begin{array}{l}0.6632 \\
0.5287 \\
0.6003 \\
0.6005 \\
0.6076 \\
0.4880\end{array}$ & $\begin{array}{l}0.5533 \\
0.5723 \\
0.5614 \\
0.5583 \\
0.5547 \\
0.5673\end{array}$ & $\begin{array}{l}0.2460 \\
0.1478 \\
0.0306 \\
0.0072 \\
0.0025 \\
0.0469\end{array}$ & $\begin{array}{l}0.6444 \\
0.6920 \\
0.8377 \\
0.9738 \\
1.0778 \\
0.8339\end{array}$ \\
\hline $\begin{array}{l}2 \text { minute } \\
\text { glaze ice }\end{array}$ & $\begin{array}{l}1 \\
2 \\
3 \\
4 \\
5 \\
6\end{array}$ & $\begin{array}{l}0.0275 \\
0.8753 \\
1.1001 \\
1.2008 \\
1.2009 \\
1.0173\end{array}$ & $\begin{array}{l}0.8056 \\
0.5081 \\
0.4956 \\
0.4887 \\
0.4722 \\
0.4752\end{array}$ & $\begin{array}{l}0.0278 \\
0.1221 \\
0.0064 \\
0.0929 \\
0.4326 \\
0.5809\end{array}$ & $\begin{array}{l}0.8100 \\
0.7527 \\
0.9945 \\
0.7428 \\
0.5728 \\
0.5308\end{array}$ & ביב & $\bar{Z}$ & $\begin{array}{l}0.0853 \\
0.0077 \\
0.0086 \\
0.0855 \\
0.1679 \\
0.1418\end{array}$ & $\begin{array}{l}0.7237 \\
0.9958 \\
0.9836 \\
0.7703 \\
0.6851 \\
0.6896\end{array}$ \\
\hline $\begin{array}{l}5 \text { minute } \\
\text { glaze ice }\end{array}$ & $\begin{array}{l}1 \\
2 \\
3 \\
4 \\
5 \\
6 \\
7 \\
8 \\
9\end{array}$ & $\begin{array}{l}0.1878 \\
0.1082 \\
0.0525 \\
0.4966 \\
0.4844 \\
0.8144 \\
1.0663 \\
0.4734 \\
0.6399\end{array}$ & $\begin{array}{l}0.6531 \\
0.6899 \\
0.7490 \\
0.5613 \\
0.5403 \\
0.4686 \\
0.4734 \\
0.5289 \\
0.4998\end{array}$ & $\begin{array}{l}0.0636 \\
0.0424 \\
0.0441 \\
0.0008 \\
0.0036 \\
0.0084 \\
0.1469 \\
0.3364 \\
0.4072\end{array}$ & $\begin{array}{l}0.7499 \\
0.7782 \\
0.7710 \\
1.1654 \\
1.0192 \\
0.9038 \\
0.6544 \\
0.5592 \\
0.5400\end{array}$ & & $\bar{m}$ & $\begin{array}{l}0.1472 \\
0.0768 \\
0.0681 \\
0.0012 \\
0.0104 \\
0.0149 \\
0.0403 \\
0.2831 \\
0.2197\end{array}$ & $\begin{array}{l}0.6824 \\
0.7292 \\
0.7328 \\
1.1424 \\
0.9457 \\
0.8842 \\
0.7992 \\
0.6174 \\
0.6378\end{array}$ \\
\hline $\begin{array}{l}15 \text { minute } \\
\text { glaze tce }\end{array}$ & $\begin{array}{r}1 \\
2 \\
3 \\
4 \\
5 \\
6 \\
7 \\
8 \\
9 \\
10 \\
11 \\
12 \\
13 \\
14 \\
15 \\
16 \\
17\end{array}$ & $\begin{array}{l}0.0915 \\
0.0757 \\
0.0500 \\
0.0495 \\
0.0358 \\
0.0340 \\
0.0327 \\
0.0281 \\
1.1024 \\
0.5132 \\
0.4821 \\
0.3085 \\
0.3219 \\
0.2922 \\
0.1206 \\
0.1259 \\
0.1265\end{array}$ & $\begin{array}{l}0.7364 \\
0.7400 \\
0.7663 \\
0.7658 \\
0.7854 \\
0.7829 \\
0.7827 \\
0.7979 \\
0.5387 \\
0.5207 \\
0.5105 \\
0.5344 \\
0.5208 \\
0.5254 \\
0.6073 \\
0.6215 \\
0.6166\end{array}$ & $\begin{array}{l}0.0163 \\
0.0124 \\
0.0145 \\
0.0156 \\
0.0187 \\
0.0204 \\
0.0153 \\
0.0139 \\
0.0059 \\
0.0347 \\
0.1026 \\
0.1224 \\
0.1562 \\
0.1522 \\
0.0647 \\
0.0632 \\
0.0810\end{array}$ & $\begin{array}{l}0.9081 \\
0.9195 \\
0.8941 \\
0.8804 \\
0.8526 \\
0.8338 \\
0.8575 \\
0.8735 \\
1.0452 \\
0.7798 \\
0.6575 \\
0.6208 \\
0.5857 \\
0.5847 \\
0.6644 \\
0.6828 \\
0.6609\end{array}$ & $\begin{array}{l}0.1177 \\
0.0950 \\
0.0593 \\
0.0621 \\
0.0474 \\
0.0488 \\
0.0421 \\
0.0432 \\
0.8322 \\
0.3698 \\
0.2487 \\
0.2058 \\
0.2205 \\
0.1829 \\
0.1211 \\
0.1761 \\
0.2134\end{array}$ & $\begin{array}{l}0.7142 \\
0.7187 \\
0.7499 \\
0.7447 \\
0.7594 \\
0.7504 \\
0.7588 \\
0.7595 \\
0.5819 \\
0.5885 \\
0.6121 \\
0.6196 \\
0.6077 \\
0.6179 \\
0.6502 \\
0.6474 \\
0.6260\end{array}$ & $\mid \begin{array}{l}0.0283 \\
0.0194 \\
0.0194 \\
0.0236 \\
0.0242 \\
0.0263 \\
0.0209 \\
0.0213 \\
0.0121 \\
0.0421 \\
0.0495 \\
0.0463 \\
0.0444 \\
0.0356 \\
0.0288 \\
0.0511 \\
0.0541\end{array}$ & $\begin{array}{l}0.8596 \\
0.8794 \\
0.8664 \\
0.8431 \\
0.8289 \\
0.8104 \\
0.8285 \\
0.8337 \\
1.0021 \\
0.8029 \\
0.7713 \\
0.7633 \\
0.7598 \\
0.7755 \\
0.8005 \\
0.7699 \\
0.7658\end{array}$ \\
\hline $\begin{array}{l}15 \text { minute } \\
\text { rime ice }\end{array}$ & $\begin{array}{r}1 \\
2 \\
3 \\
4 \\
5 \\
6 \\
7 \\
8 \\
9 \\
10\end{array}$ & \begin{tabular}{l}
0.3093 \\
0.1543 \\
0.0313 \\
0.0352 \\
\hdashline.- \\
0.0043 \\
1.0146 \\
1.2511
\end{tabular} & $\begin{array}{l}0.6136 \\
0.6733 \\
0.7999 \\
0.7958 \\
0.2 \\
0.9844 \\
0.5030 \\
0.4831\end{array}$ & $\begin{array}{l}0.0231 \\
0.0493 \\
0.0384 \\
0.0356 \\
0.0509 \\
0.0888 \\
0.0807 \\
0.0048 \\
0.2548 \\
0.8081\end{array}$ & $\begin{array}{l}0.8781 \\
0.8015 \\
0.8151 \\
0.8256 \\
0.7993 \\
0.7546 \\
0.7772 \\
1.0468 \\
0.6447 \\
0.5342\end{array}$ & $\begin{array}{l}0.0613 \\
0.0267 \\
0.0089 \\
0.0187 \\
0.0126 \\
0.0095 \\
0.0405 \\
0.0785 \\
0.6615 \\
0.6449\end{array}$ & $\begin{array}{l}0.7549 \\
0.8256 \\
0.9078 \\
0.8491 \\
0.8895 \\
0.9125 \\
0.7858 \\
0.7653 \\
0.5726 \\
0.5740\end{array}$ & $\begin{array}{l}0.0201 \\
0.0352 \\
0.0265 \\
0.0197 \\
0.0367 \\
0.0494 \\
0.0645 \\
0.0408 \\
0.1569 \\
0.1953\end{array}$ & $\begin{array}{l}0.8973 \\
0.8395 \\
0.8571 \\
0.8863 \\
0.8371 \\
0.8138 \\
0.8035 \\
0.8750 \\
0.7187 \\
0.6898\end{array}$ \\
\hline
\end{tabular}




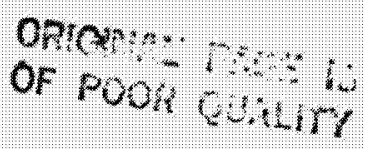

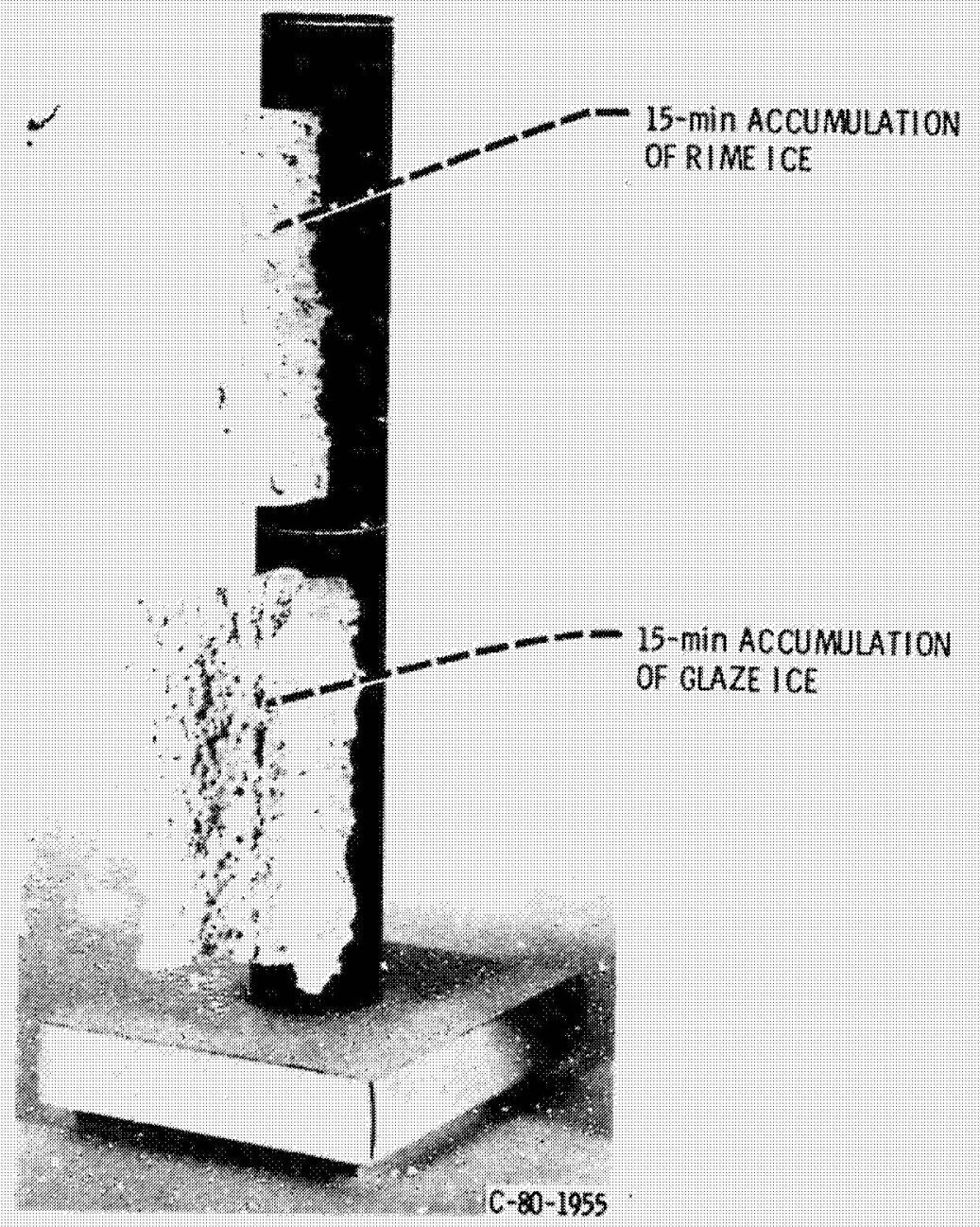

Figure 1. - Plaster casts of 15-min accumulafion of both rime and glaze ice on a $5.1 \mathrm{~cm}$ (2.0 in. $)$ diameter cylinder. 


\section{ORIGINAL PAQE IS}

OF POOR QUALITY

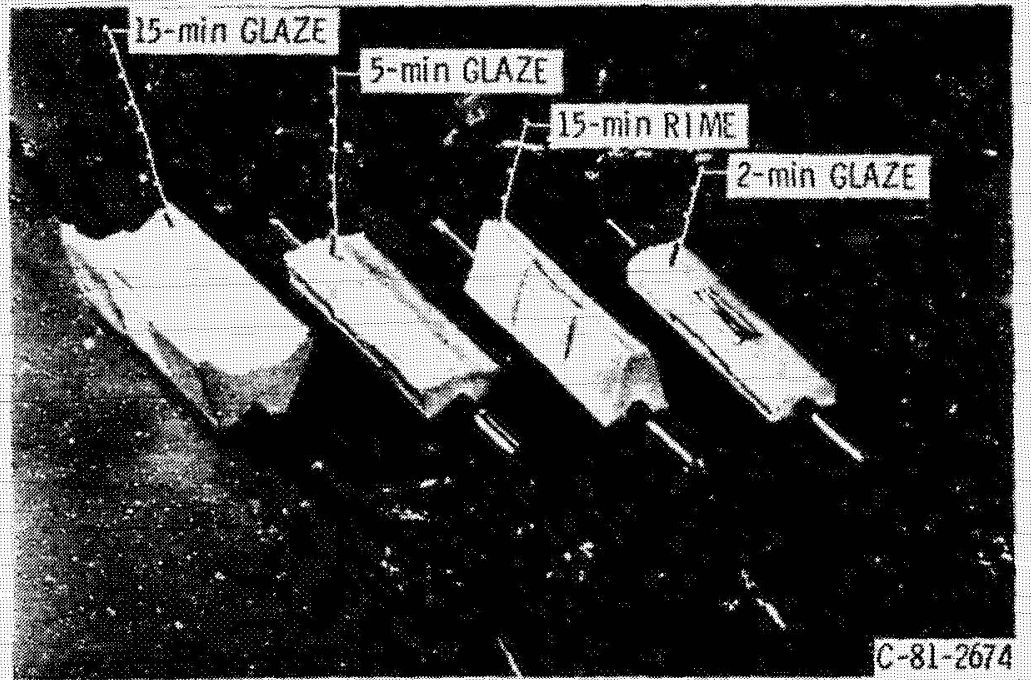

Floure 2. Photograph of icing shape heat transter models.

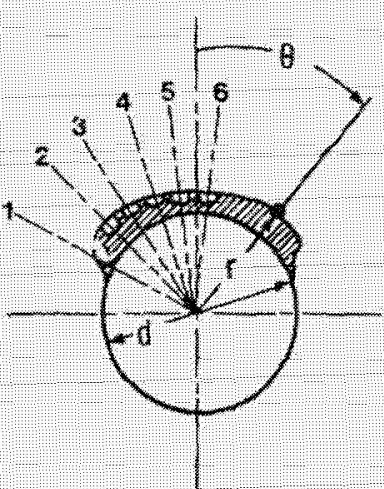

(a) Two minute glaze lice.

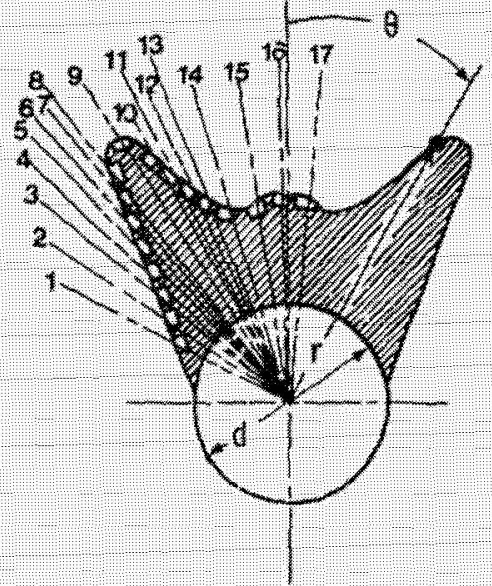

(c) Fifteen minute glaze ice.

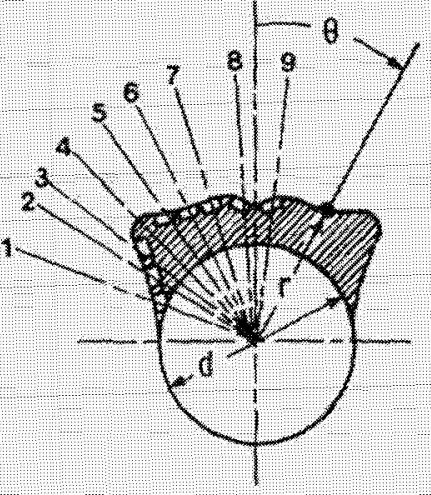

(b) Five minute glaze ice,

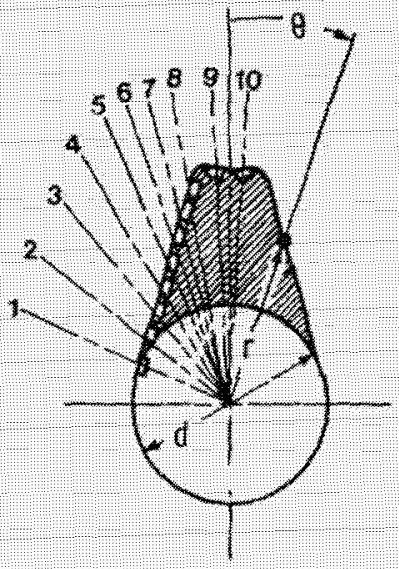

(d) Fifteen minute rime lce.

Figure 3. - Ice shape cross sections she.i. ig profile coordinates and heat flux yage locations. 


\section{ORIN}

OF :

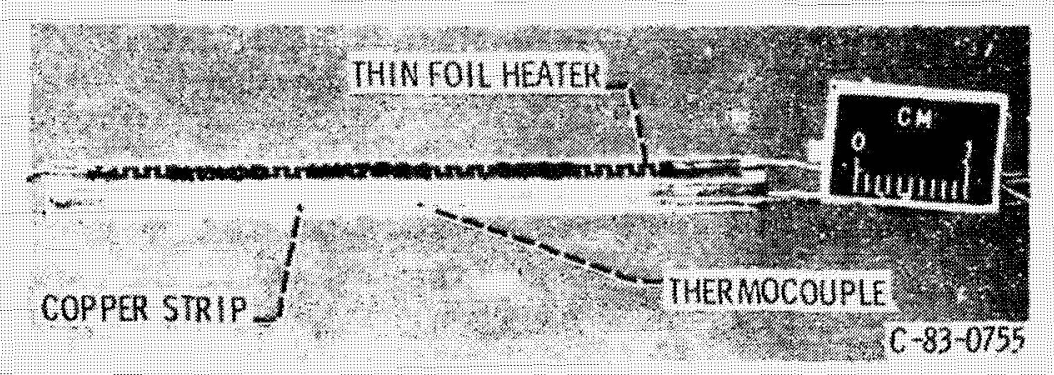

Figure 4 - Photograph of heat flux guage.

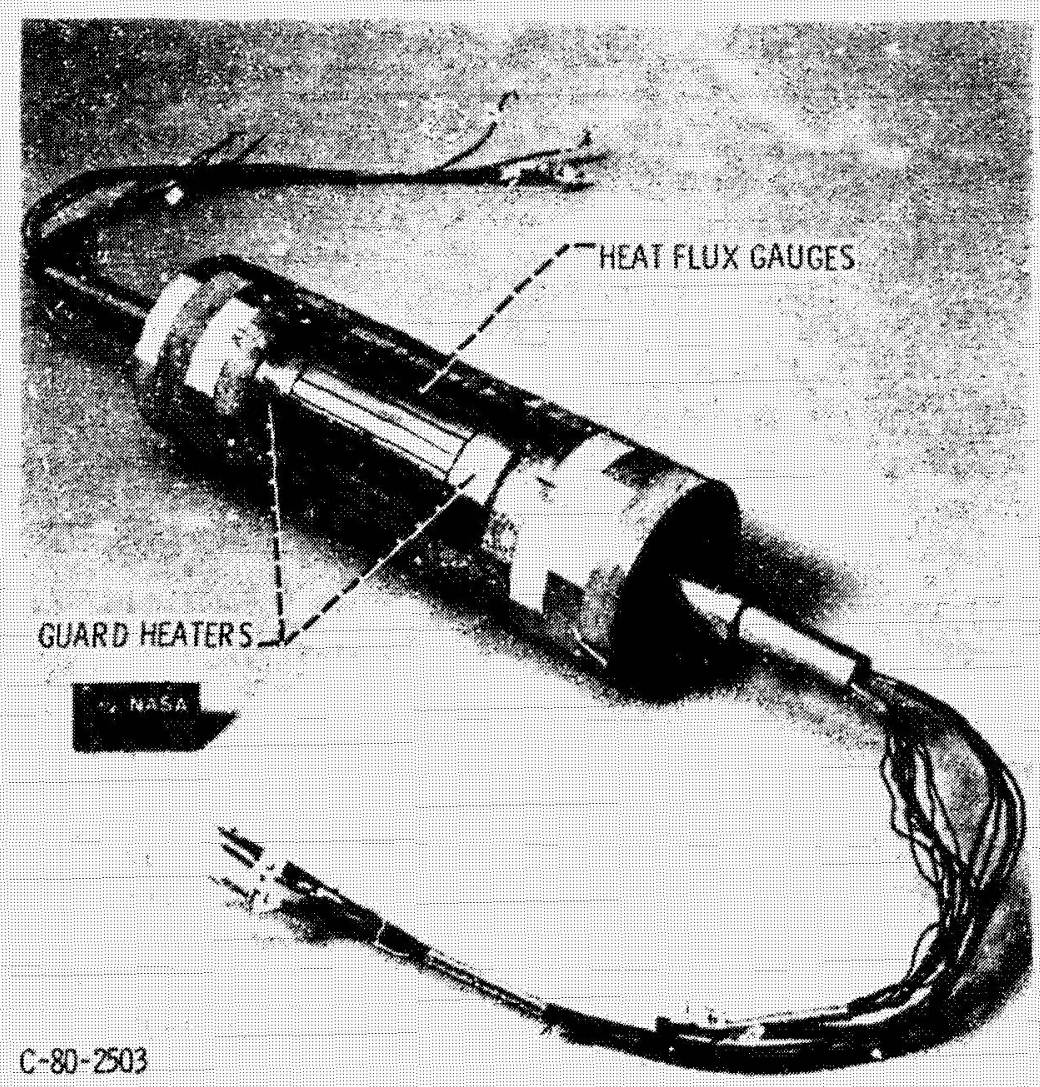

Figure 5. - Cylinder heat transfe! model. 
ORICINAL PAGE I:

OF POOR QUALITY

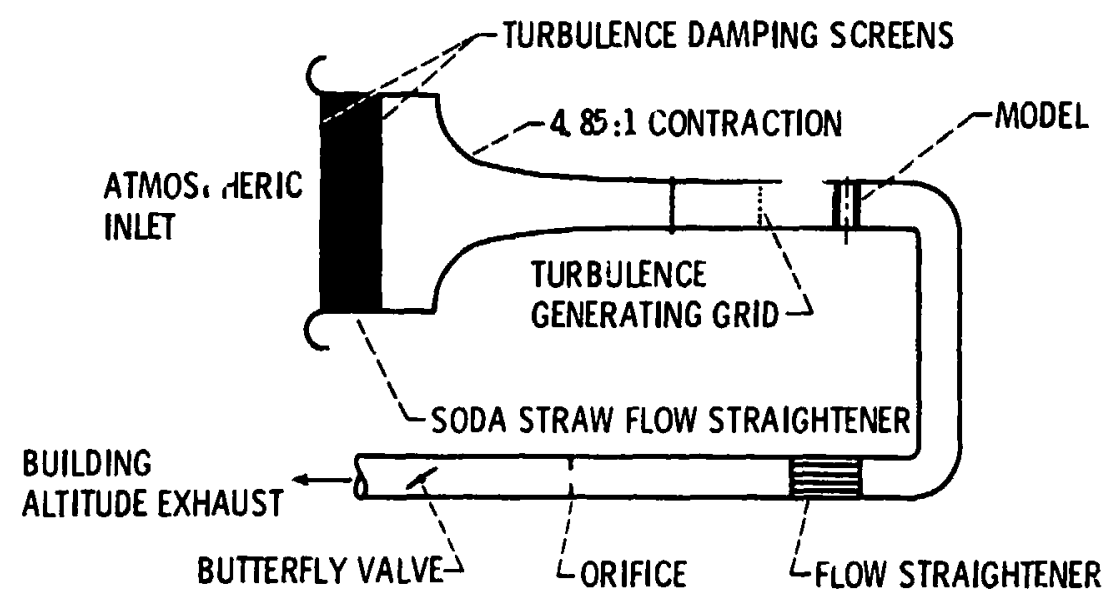

Figure 6. - Wind tunnel schematic.

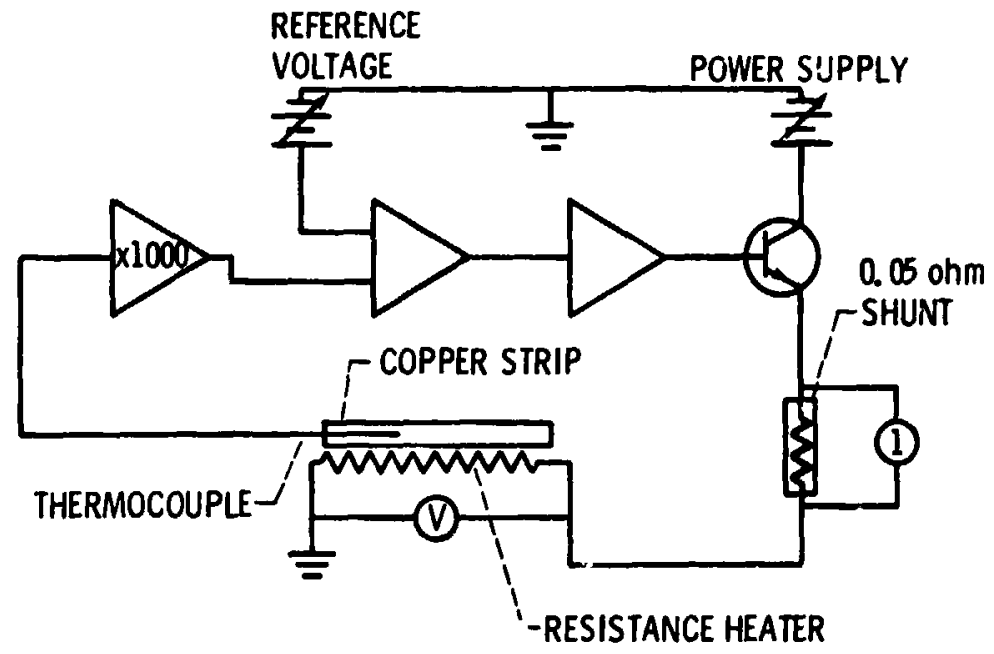

Figure 7. - Schematic of automatic heat flux gage tempr"ature controlier. 


\section{ORIGINAL PAGE IS \\ OF POOR QUALITY}
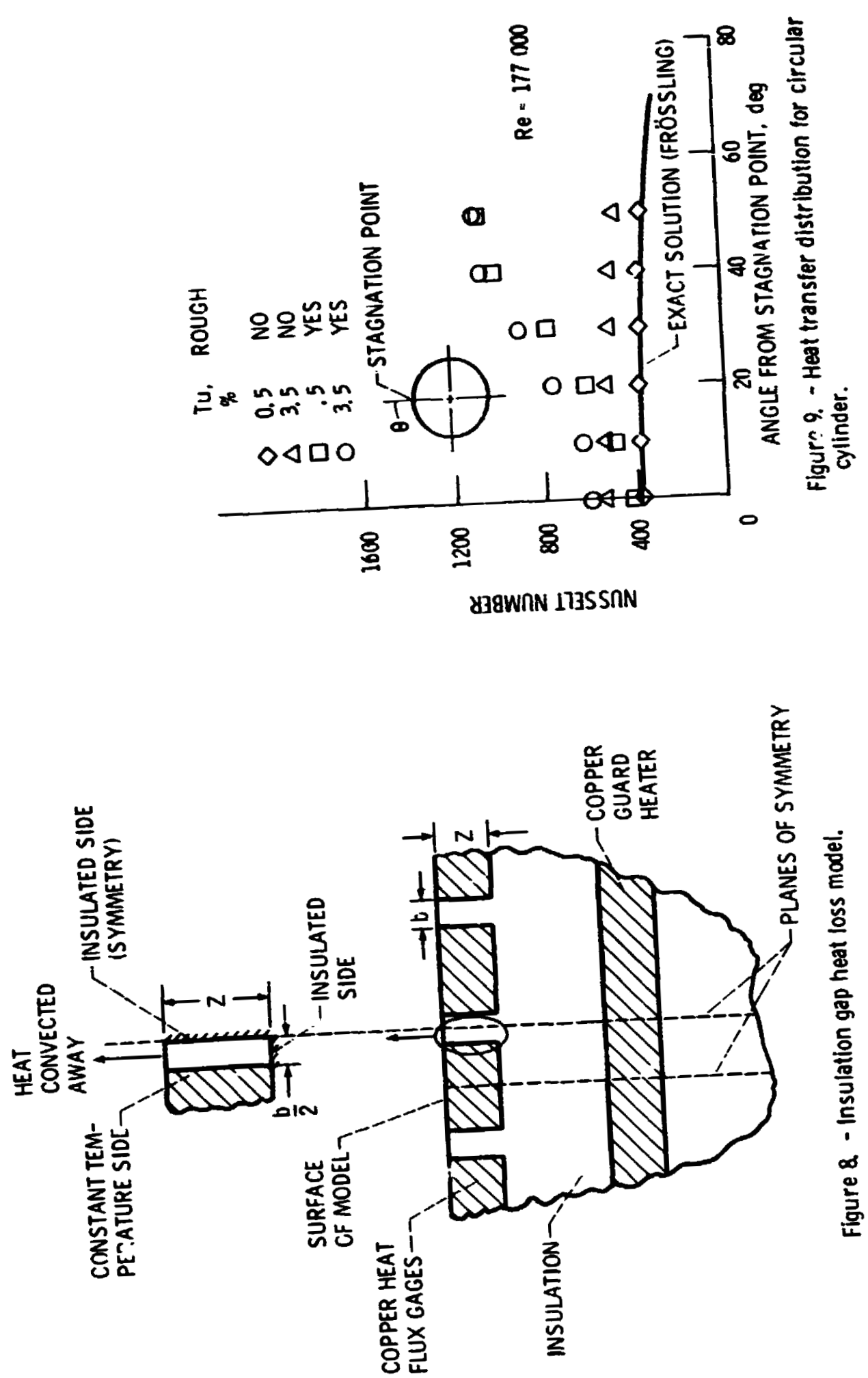
ORIGNAL PAGE IS
OF POOR QUALITY

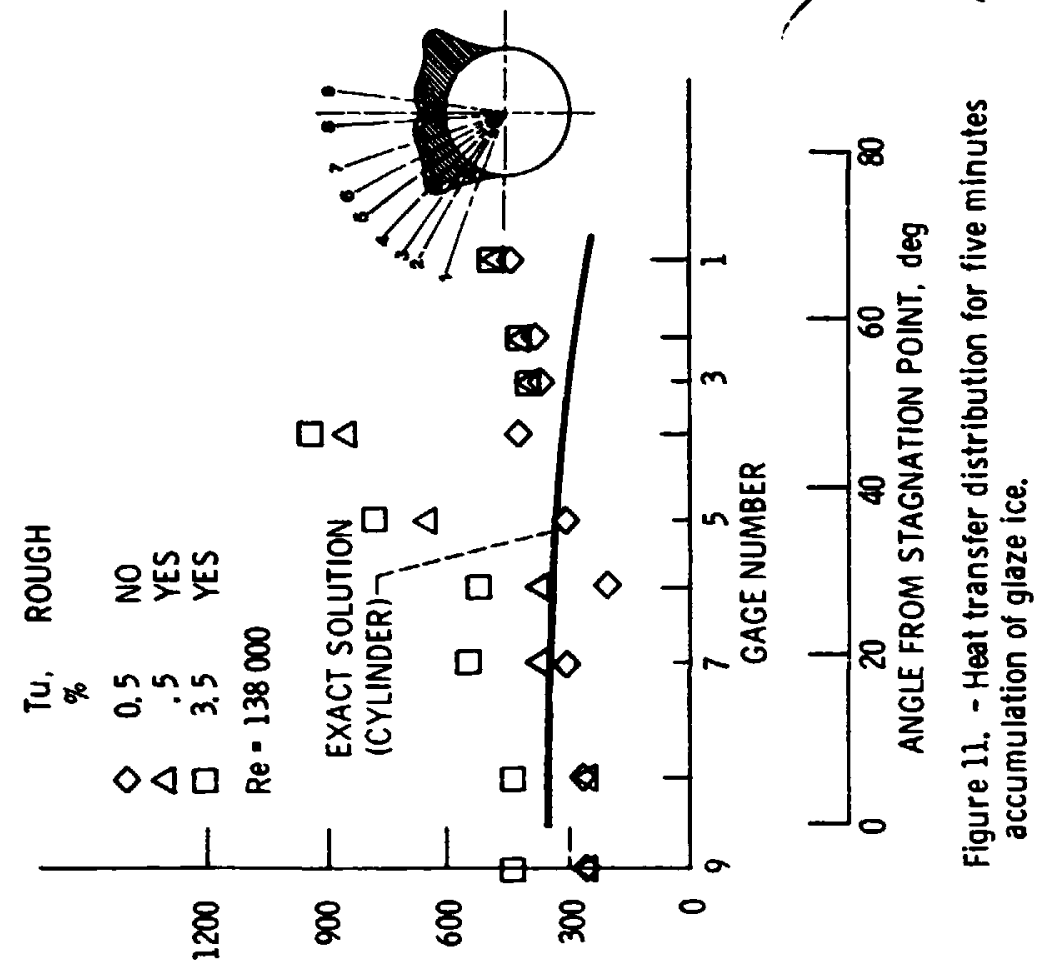

JتGWกN I7GSSกN

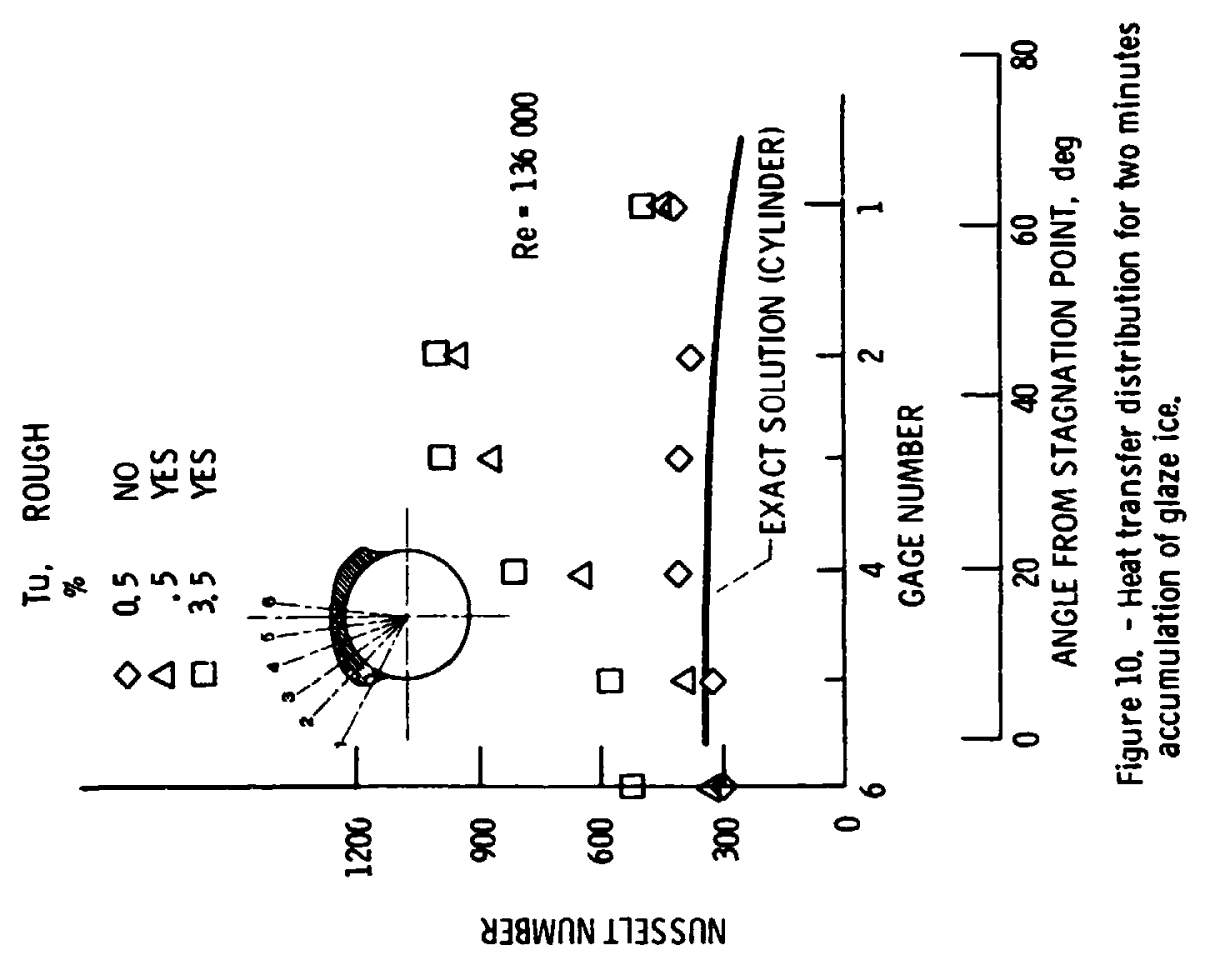




\section{ORIGNAL FALE i
OF POOR QUALITY}
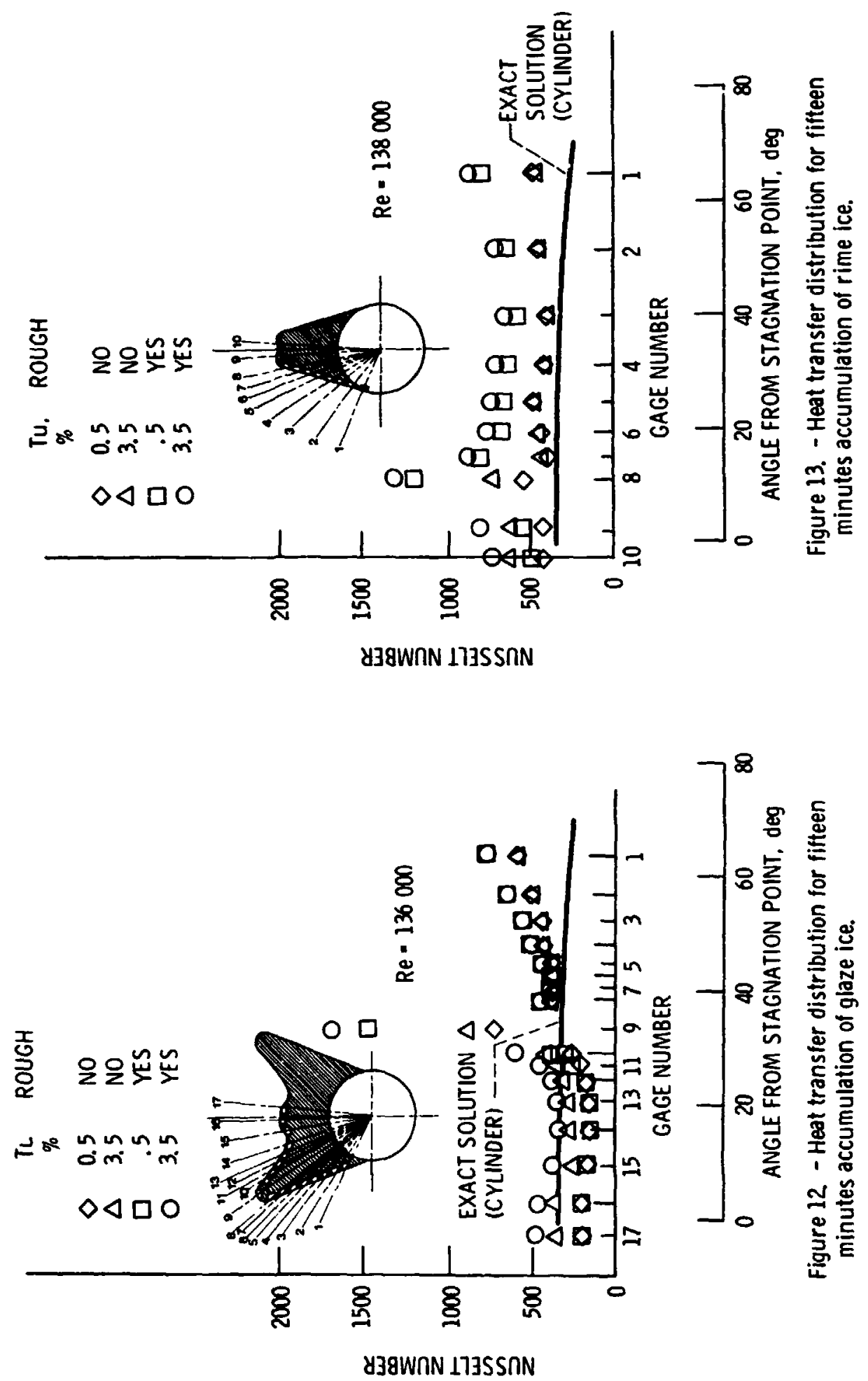


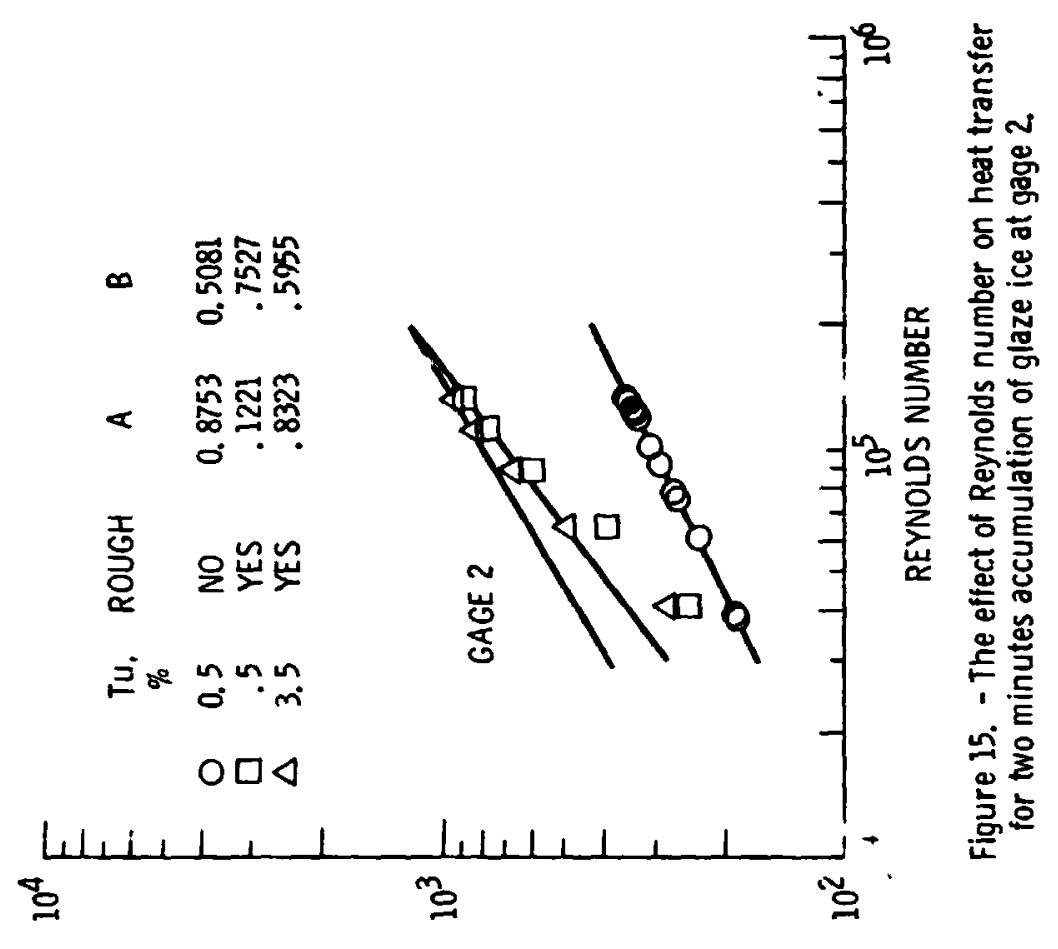

Z3QWกN IIJSSกN

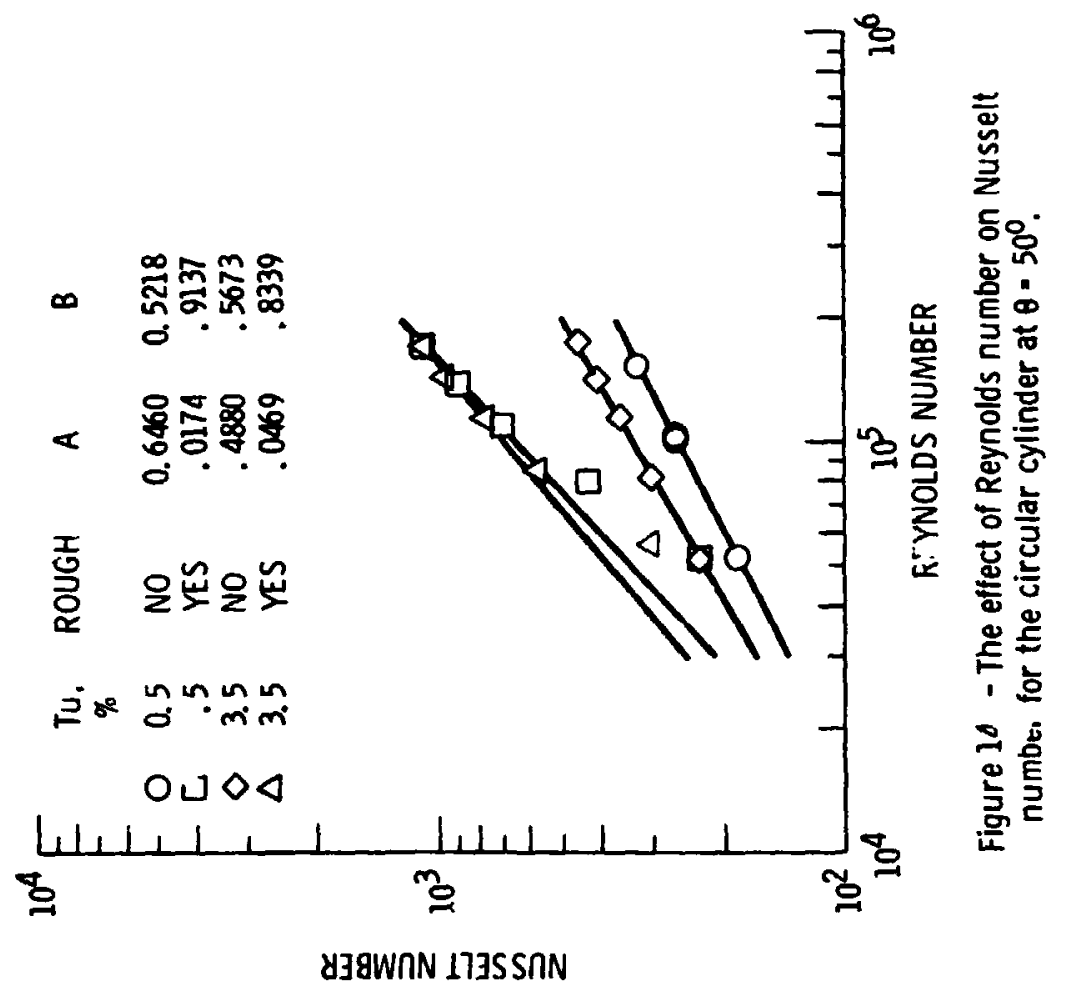




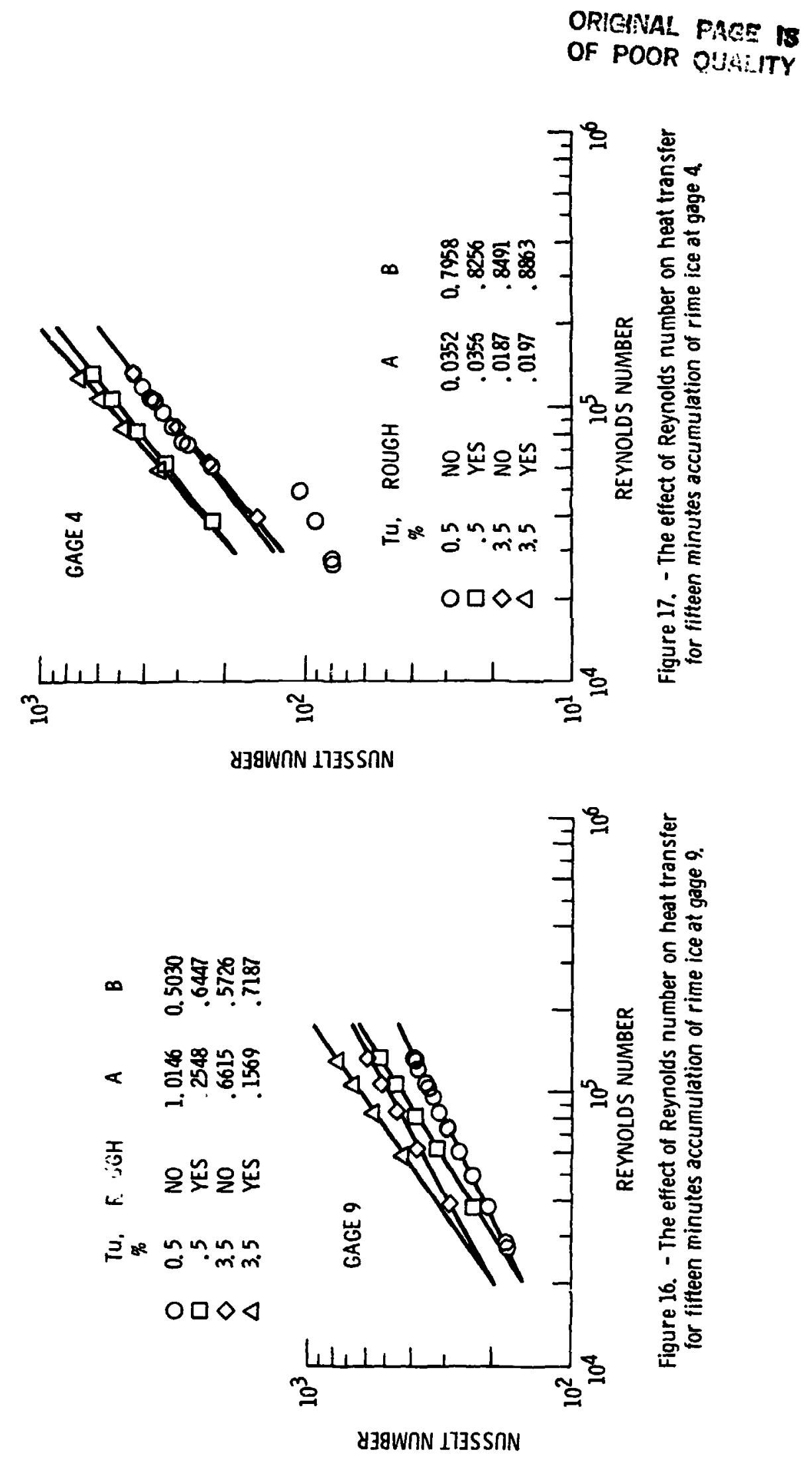

